\title{
The counter-terrorist campus: Securitisation theory and university securitisation - Three Models
}

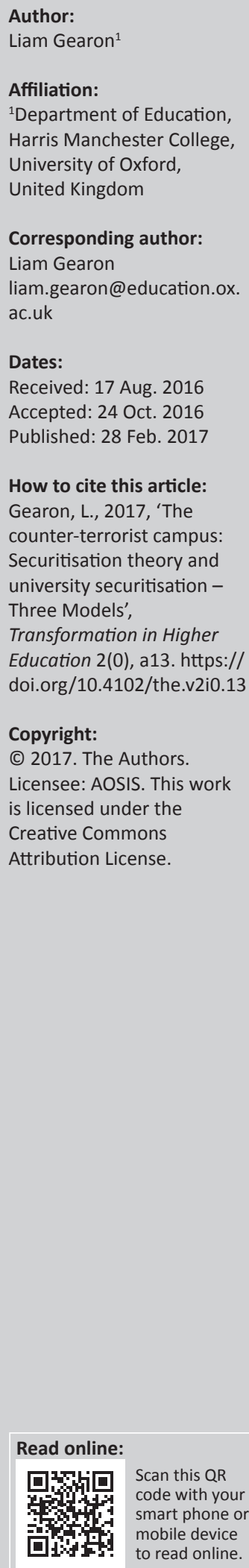

With intensified threats to global security from international terrorism, universities have become a focus for security concerns and marked as locus of special interest for the monitoring of extremism and counter-terrorism efforts by intelligence agencies worldwide.

Drawing on initiatives in the United Kingdom and United States, I re-frame three - covert, overt and covert-overt - intersections of education, security and intelligence studies as a theoretical milieu by which to understand such counter-terrorism efforts.

Against the backdrop of new legislative guidance for universities in an era of global terrorism and counter-terrorism efforts by security and intelligence agencies and their Governments, and through a review of Open-Source security/intelligence concerning universities in the United Kingdom and the United States, I show how this interstitial (covert, overt and covertovert) complexity can be further understood by the overarching relationship between securitisation theory and university securitisation.

An emergent securitised concept of university life is important because de facto it will potentially effect radical change upon the nature and purposes of the university itself.

A current-day situation replete with anxiety and uncertainty, the article frames not only a sharply contested and still unfolding political agenda for universities but a challenge to the very nature and purposes of the university in the face of a potentially existential threat. Terrorism and counterterrorism, as manifest today, may well thus be altering the aims and purposes of the university in ways we as yet do not fully know or understand. This article advances that knowledge and understanding through a theoretical conceptualisation: the counter-terrorist campus.

\section{Introduction}

In 2013 I published an article for the long-established US journal Religious Education entitled 'The Counter Terrorist Classroom' (Gearon 2013b) following a foundational theoretical paper, 'The Securitization of Religious Education' (Gearon 2012b). The article addressed some pertinent issues around the intensified political and security themes in religious education classrooms. From this article and other publications (Gearon 2012a, 2013a, 2015a, 2015b), I have contributed two conceptual frames to the broad field at the intersection of religion in education, 'the politicisation of religion in education' and 'the securitisation of religion in education'. My basic argument, drawing on historical and contemporary analyses of the relationship between religion, politics, and pedagogy (Gearon 2008; also Gearon 2002a, 2002b, 2003; cf. De Forest 2004) was that a determinable trend to use religion in education for political purposes had become subject to security agendas. One particular focus here had been the Organisation for Security and Cooperation in Europe (the OSCE) and its widely promulgated policy document The Toledo Guiding Principles on Teaching about Religions and Beliefs in Public Schools (OSCE 2007). I sought to ask a simple question, why was a body such as the OSCE, of Cold War origins, interested in the teaching of religion in schools? This was part of an evidential base of international policy initiatives - including statements to the Human Rights Council of the United Nations by the Special Rapporteur for Freedom of Religion or Belief advocating the Toledo model - that led me to conceptualise how a politicisation of religion in education had increasingly become marked by a securitisation (for a trenchant critique of my analysis, see Jackson 2015; my response will be published as part of the forthcoming proceedings of the triennial $-2016-12^{\text {th }}$ International Nuremberg Forum, for an abstract see Gearon 2016).

In a Special Issue of the British Journal of Educational Studies on Education, Security and Intelligence Studies (Gearon 2015a) I provided some wider and deeper frames of reference to the historical as well as sharply emergent new relationship between education, security and intelligence studies. I identified three main aspects to the interface: the covert, the overt and the covert-overt. 
In this article, I show how this analysis has particular relevance to universities in the light of intensified threats to global security from international terrorism argue that universities have become a focus for security concerns and marked as locus of special interest for the monitoring of extremism and counter-terrorism efforts by intelligence agencies worldwide.

Drawing on initiatives in the United Kingdom and United States, I reframe three - covert, overt and covert-overt intersections of education, security and intelligence studies as a theoretical milieu by which to understand such counterterrorism efforts.

Against the backdrop of new legislative guidance for universities in an era of global terrorism and counterterrorism efforts by security and intelligence agencies and their Governments, and through a review of Open-Source security/intelligence concerning universities in the United Kingdom and the United States, I show how this interstitial (covert, overt and covert-overt) complexity can be further understood by the overarching relationship between securitisation theory and university securitisation.

An emergent securitised concept of university life is important because de facto it will potentially effect radical change upon the nature and purposes of the university itself.

A current-day situation replete with complexity, as well as anxiety and uncertainty, the article frames not only a sharply contested and still unfolding political agenda for universities but a challenge to the very nature and purposes of the university in the face of a potentially existential threat. Terrorism and counter-terrorism, as manifest today, may well thus be altering the aims and purposes of the university in ways we as yet do not fully know or understand. This article is an attempt to further that knowledge and understanding through a theoretical conceptualisation, the counter-terrorist campus.

\section{Terrorism and counter-terrorism: Education, security and intelligence}

In 1955, Sherman Kent, former Yale Professor, himself now with a role within the newly formed US Central Intelligence Agency (CIA), provided a defining call for the professionalisation of the (US) security and intelligence agencies (Allen 1985; Dulles 2006; Felix 1992; Shulsky 2001) but their rootedness in their own disciplinary identity and academic literature:

Intelligence today is not merely a profession, but like most professions it has taken on the aspects of a discipline. It has developed a recognised methodology; it has developed a vocabulary; it has developed a body of theory and doctrine; it has elaborate and refined techniques. It now has a large professional following. What it lacks is a literature. (Kent 1955:3; see also Kent 1966, 1968)

As Davies states, 'Virtually all intelligence theory could be considered a footnote to Kent'. Kent's conviction was that intelligence should be 'a broad-based analytical discipline' established 'the precedent for most subsequent debate' and was embodied by the maxim, 'intelligence is knowledge' (Davies 2002).

Today, Kent's framing has produced not only a literature but a complex of 'Intelligence Collection Disciplines' (Lowenthal \& Clark 2015; Walton 2010) which includes Human Intelligence; Signals Intelligence, Imagery Intelligence, Measurement and Signatures Intelligence, and, critically, Open-Source Intelligence (OSINT). The latter demonstrates the real breadth of intelligence gathering. Defined by one US agency as the 'broad array of information and sources that are generally available, including information obtained from the media (newspapers, radio, television, etc.), professional and academic records (papers, conferences, professional associations, etc.), and public data (government reports, demographics, hearings, speeches, etc.)' (FBI 2016). It is in and through OSINT, which sweeps up any knowledge source not covered by the more operational, technical, technological and generally more directly open military and covertly espionage-related activity.

There is thus a correlation between the new and now established diversity of intelligence disciplines and a proliferation of security-intelligence interest in a variety of forms and sources of knowledge (Buzan \& Hansen 2009; Buzan, Waever \& Wilde 1998). This is a breadth of interest inconceivable at the origins of Britain's security and intelligence organisations, MI5 (the Security Service) (Andrew 2010), MI6 (the Secret Intelligence Service, SIS) (Jeffrey 2011) or the Government Communications Headquarters (GCHQ) surveillance centre (Aldrich 2011); the founding focus of two of these being given by their codenames, the M which prefaces the famous bodies of MI5 and MI6 imputes 'military'. If the M-preface has remained, a narrow military focus has changed irrevocably.

The present-day process of extension of security and intelligence interest emerged, most scholars agree, in the Cold War when intelligence came to be seen as essential to peacetime as to war (Dulles 2006; Felix 1992; Herman 1996; Shulsky 2001). Here the Cold War witnessed the opening of an ideological front, which meant that ideas as much as arms were critical in a battle fought as much over ideology and propaganda as on the battlefield. Risso's (2014) subtle and revelatory examination of the NATO Information Service, for example, shows just how extensive had become the cultural breadth of intelligence gathering beyond Cold War preoccupations with the arms race and nuclear proliferation.

In the academic disciplines of security and intelligence studies, this expansion of intelligence and security interests is defined by a porous delineation of two factions, 'realists' or 'traditionalists' arguing that war and military defence are the proper concern of security; and on the other hand, identified by the 'critical security project' those 'wideners' who extend security to incorporate an almost all-inclusive range of concerns for human security (culture, education, food, health, water and so forth) (Dunn Cavelty \& Mauer 2010). 
By any assessment, especially the random events of terror (as witnessed in 2016 alone), there is consensus which posits that if security is about protection against threat, such threat does not have its origins or its amelioration in military means. In these broad terms, as Cavelty and Mauer's (2010) analysis concludes, although security 'realists' still maintain their military stance the 'wideners' of the 'critical security project' have won the day, for we can see, post-Snowden, that no security analysis is preoccupied with military matters alone (Greenwald 2013, 2015; Harding 2014; Pham 2013; Svendsen 2013). Today, intelligence gathering is now potentially about everything and everyone and not merely defined enemies and adversaries (Aldrich 2014; IRISS 2015; Wright \& Kreissl 2013). It is by such moves that universities - as loci for knowledge generation - have become a critically important element in the unfolding, widening and deepening of security/intelligence knowledge gathering.

Intelligence and security agencies have far wider interests than terrorism and counter-terrorism. But today for self-evident reasons, these matters are of high priority. In the United Kingdom, counter-terrorism measures include Channel and Prevent, underpinned by the Security and Counter-Terrorism Act 2015 (UK Gov 2015). Pan-European counter-terrorism initiatives, which are presented with their own challenges now the United Kingdom have opted for 'Brexit', are also widespread (Argomanis 2009; Argomanis, Bures \& Kaunert 2014; Bakker 2014; Bellaby 2012). The U.S. Department for Homeland Security is one of many agencies directed towards counter-terrorism and related threats (DHS 2015).

Academic terrorism studies and research are themselves now an established sub-discipline within security and intelligence studies, and though this is a relatively recent history it is, has been - pre- and post-9/11 - an extraordinarily intense one (Breen-Smyth et al. 2008). Definitions of terrorism and by logic therefore counter-terrorism - are themselves as diverse as the field itself is contested (Gunning 2007). In the encyclopaedic Handbook of Terrorism Research, Schmid (2011:39-98, 99-157) identifies over 250 'academic, governmental and intergovernmental' definitions. The relationship between terrorism and religion has of course come into contemporary focus but is of considerable typological range (Schmid 2011:23-27; bibliographical sources, 532-539). I understand this notional counter-terrorism in broad terms as one of threat, it being existential in the sense it poses a threat to life. Operationally and academically, this education, security and intelligence interface has long been concerned with an expanding notion of threat, beyond, that is, military associations of defence and warfare. Operational frameworks to counter threat meet here academically at an interface of education, security and intelligence studies.

Education is defined here by its institutional contexts and formal settings where universities are concerned with the specific perceived benefits and opportunities provided by their privileged access to knowledge. This nexus of education, security and intelligence is not new, but it has intensified.
Both operationally and academically, the interface of education, security and intelligence has become more entangled. As the intensification of threat has widened so too have interests in the security and intelligences services, as directed by the governments they serve, widened and deepened their interest in universities.

Thus, amidst ever-increasing threats to global security from international terrorism universities have become intensified foci for security concerns and marked as loci of special interest for the monitoring of extremism as well as the mobilisation of counter-terrorism efforts by intelligence agencies worldwide. In the United Kingdom, for instance, the Security and Counter-Terrorism Act 2015 (UK Gov 2015) places new and direct responsibilities upon public bodies systematically to monitor and report on extremism and suspected terrorist activities, a move which on campuses has provoked some trenchant responses from universities (UUK 2012). In the United States, the relationship between universities and security and intelligence agencies has, at least over the last decade, become more engrained, with initiatives such as the Intelligence Community Centers for Academic Excellence (IC CAE) programme (ODNI 2005) and the subsequent formation of the International Association for Intelligence Education (IAFIE). Both the latter initiatives have been modelled on a close interrelationship between universities and the intelligence agencies such as the US's CIA and the Federal Bureau of Intelligence (FBI).

Such types of securitisation - for this is inevitably how they must be defined - has encountered impassioned oppositions from many academic quarters, from university institutions and academic community alike (Durodie 2016; Glees 2015). These concerns, tensions and resistances to securitisation are also integral to security and intelligence studies as a discipline.

It is this same tension in the field of security and intelligence studies, which finds itself articulated in more sporadic, less systematic ways in university responses to the securitisation of their campuses and academic life.

\section{Securitisation theory and university securitisation}

An accessible and valuable synthesis of securitisation theory and securitisation studies is thus provided by Rita Taureck (2006). She frames securitisation theory as follows:

\footnotetext{
A securitising move is in theory an option open to any unit because only once an actor has convinced an audience (inter-unit relations) of its legitimate need to go beyond otherwise binding rules and regulations (emergency mode) can we identify a case of securitisation. In practice, securitisation is thus far from being open to all units and their respective subjective threats. Rather, it is largely based on power and capability and therewith the means to socially and politically construct a threat. In this way the study of security remains wide, but with restrictions pertaining to 'who' can securitise, it is neither unmanageable nor incoherent.
} 
The main argument of securitisation theory, she states, is that, 'security is a (illocutionary) speech act, that solely by uttering "security" something is being done'. 'It is by labelling something a security issue that it becomes one' (Taureck 2006; Wæver 2004:13).

By stating that a particular referent object is threatened in its existence, a securitising actor claims a right to extraordinary measures to ensure the referent object's survival. The issue is then moved out of the sphere of normal politics into the realm of emergency politics, where it can be dealt with swiftly and without the normal (democratic) rules and regulations of policymaking. For security, this means that it no longer has any given (pre-existing) meaning but that it can be anything a securitising actor says it is. Security is a social and intersubjective construction. That is the meaning of security (Taureck 2006).

This process of securitisation can be applied to a wide range of factors, situations, as the critical security project asserts, almost anything. For Taureck (2006):

To prevent 'everything' from becoming a security issue, a successful securitisation consists of three steps. These are (1) identification of existential threats, (2) emergency action and (3) effects on inter-unit relations by breaking free of rules.

Following Buzan et al. (1998:6), for a situation to be securitised, then an existential threat must be posed; or as Buzan et al. state, 'If we do not tackle this problem, everything else will be irrelevant (because we will not be here or will not be free to deal with it in our own way)' (Buzan et al. 1998:24). Such a 'securitising move' is the first step in the process of securitisation.

In these terms, while comparative international data are sorely lacking, UK and US campuses at least can be said to have been (at least in part) securitised, have undergone some 'securitising move' as Taureck puts it:

in light, that is, of being utilised for either the furthering of security and intelligence aims and purposes through teaching and research or by becoming subject to legislation which compels them to comply with a Government set security and intelligence agenda, here the countering of violent extremism and or terrorism.

It is arguably this very sense of securitisation that universities, by being subject to such initiatives, are moving 'out of the sphere of normal politics', certainly out of what are perceived to be normal university politics, that may be the unstated, perhaps unrecognised concern of universities.

More fundamental, then, than any of the explicitly made concerns expressed by universities and academics, I contend, as a hypothesis, that:

it is not the specifics of challenge to academic integrity nor academic freedom or ethics or even intrusion that is resented and (within the legal limits of which this is possible) resisted but the very process of securitisation itself.

We find this very same resistance mirrored in more explicit terms within the field of securitisation theory. For Taureck, securitisation theory is 'a tool for practical security analysis' (and here we must bear in mind the limited sense in which an issue can become a security issue). She defends proponents of this view, notably Wæver (as cited), against the 'moral and ethical' criticism levelled against it by scholars such as Aradau (2004) and Huysmans (1995). The moral and ethical concern is evident in challenges to the processes of securitisation into human (cultural, economic, health, social and political) life which - so such critics argue - provide not security and flourishing of the human subject but its endangerment.

If we return to the issue of university securitisation, a simple example of this can be provided through the almost universally negative response initially by schools and (now that it explicitly applies to them) universities to the UK Government's Prevent in all its manifestations, under successive Labour, Liberal-Conservative and Conservative administrations. In other words, the negative reaction is not so much political, still less party political, than negative as to the very processes of security intrusion itself. Thus, because the Prevent Agenda aims to prevent radicalisation and counter extremism, its critics will say - again universally that far from providing security for British life, it undermines it by alienating Muslim majorities, the emphasis on 'fundamental British values', which the Prevent programme also espouses simply further distancing people from them, often to the point of scorn and derision as to the notion of British values themselves (see Richardson 2015). Among the few senior UK academics who challenge this scepticism is Glees (2015) for which exercise of academic free expression he has been subject to criticism (Durodie 2016).

We may, therefore, albeit provisionally, assert two things: (1) in the terms just outlined, both theoretical and legislative, that universities have to some degree become subject to a securitising move, a securitisation, university securitisation; and (2) securitisation theory provides some ready-made insights into this securitisation process within and across universities; it is concerned with threat, existential threat and terrorism as life-endangering is and remains an existential threat. However, if this marks only a modest level of theoretical possibility, the state of empirical investigation is markedly even less developed.

What follows now is a hypothetical excursus, a prospective three-fold model of the notional 'counter-terrorist campus' to allow for further theoretical refinement and empirical testing. The three campus model is presented in ways which are intended to focus the broad terms of the theoretical framing securitisation theory and university securitisation, to make more precise the future locus/loci for any said empirical investigation.

\section{The counter-terrorist campus: Three models}

Although a typological analysis of more nuanced disciplinary or institutional complexity would be most welcome here, suffice to say that an historically rooted (see, for example, 
Sinclair 1986; Winks 1987), that is longstanding or chronic, and contemporaneously acute disciplinary and institutional relationship has and continues to exist between universities and security/intelligence agencies, between academic endeavour and security/intelligence operations.

Here we need be satisfied with an outline structural, that is relational-institutional model, with some hint of disciplinary correspondence, which reflects ways in which counter-terrorist and related security and intelligence activity is currently framed in relation to (UK and US) universities as part of the processes of securitisation: the covert model, the overt model and the covert-overt model (see also Gearon 2015a).

\section{The covert model}

The Covert Model reflects the increased, essentially postSecond World War and Cold War, professionalisation of security and intelligence as an integral aspect of defence and wider civil preparedness for terrorist and other forms of threat to national and international instability. What I have termed as 'the spy schools' (Gearon 2015a) are essentially university-level centres for education and training of espionage agents and all related activities concerned with security and intelligence gathering. The CIA defines a spy as 'someone who provides classified information about his country to another country' where 'CIA operations officers recruit foreign agents (you could also call them spies) who pass information to CIA' (CIA 2015). But the scope of what might be determined as 'the spy school' (Gearon 2015a), extensive and ever-expansive, is (because secret) only in part encapsulated by the established intelligence-gathering disciplines detailed by Lowenthal and Clark (2015) - by their very nature secret (their activities protected by high levels of security clearance) and thus, at all operational levels (planning to execution) covert.

Although, historically, the CIA (2015) notes that the 'United States has carried out intelligence activities since the days of George Washington' distinctive features of the covert model today are its professionalisation (officers and agents are initiated into a particular career pathways), its systematisation (officers and agents are initiated into organisational networks as part of a political structure) and its educational and training institutionalisation.

Thus, today the US Intelligence Community consists of numerous bodies working under the overall remit of security and intelligence - the paramount CIA for foreign intelligence, the FBI with a remit for national security with the Department of Homeland Security, the National Security Association (NSA), the National Geo-Spatial Agency, along with military intelligence departments of Army, Air Force, Navy and Special Forces, including the Marines (Johnson 2012).

With oversight and coordination through the NSA, each has largely secret and high-security educational and training establishments, a covert model which corresponds in military departments closely with the traditionalist model of security as being concerned with the explicit demands of defence and war. The wider remit of the critical security project is demonstrated by the umbrella training and education facilitated by the institutions such as the Defence Intelligence Agency (DIA). Although the DIA make explicit their primary role as providing 'military intelligence' to 'warfighters', they also make plain the parallel university-level institutional model of operation but also a drawing upon all-source intelligence gathering which presumes an implicit and close relationship between developments in knowledge in the intelligence community and knowledge generation in academia as well as developments (scientific, technological in particular) in non-university settings (DIA 2016). The most explicit parallel or covert model of high education-level training, education and research is in the US context selfevident from the relatively recent creation of the CIA University (CIA 2016).

In the United Kingdom, parallel professionalisation, systematisation and institutionalisation are evident across MI5, concerned with national security, MI6, or the SIS, concerned with foreign intelligence and the GCHQ (Aldrich 2011; Andrew 2010; Jeffrey 2011). As with the United States, army, air force and navy have their own sections concerns with Defence Intelligence (Agrell 2012; Johnson 2012; see also Aldrich 2001; Aldrich, Andrew \& Wark 2008; Aldrich, Cormac \& Goodman 2014; Dylan \& Alexander 2012). The functions, remit and limitations, including channels of accountability, were demarcated by the Security Service Act 1989 and the Intelligence Services Act 1994 (ISA) (MI6 2015), recently subject to a major review by David Anderson (2015). The Iraq Inquiry (Chilcot 2016), the UK Government-commissioned report into the Iraq War, shows the extent to which the security and intelligences agencies are not only subject to critique but also how fundamental they are to the mechanisms of government itself, yet perhaps above all how critical the information gathered is integral to policy decisions around military engagement. The UK Parliament's Joint Intelligence Committee (JIC) thus provides Ministers and senior officials with 'co-ordinated interdepartmental intelligence assessments on a range of issues of immediate and long-term importance to national interests, primarily in the fields of security, defence and foreign affairs'. JIC membership consists of the heads of MI5, MI6 and GCHQ, including those Departments of State for which intelligence information gathered is critical, including Home Office, the Foreign and Commonwealth Office and the Ministry of Defence, as well as the Treasury.

As Aldrich et al. (2014) has shown, intelligence gathering has vast scope and multi-departmental impact. In the United Kingdom as in the United States, its professionalisation, systematisation and institutionalisation demands, in terms of training, education and research a parallel, necessarily secret and operationally covert modus operandi where responsibility for education and training is maintained by UK Ministry of Defence, and within the intelligence-gathering agencies of MI5, MI6 and GCHQ, which, as within the United States, will remain, operationally, secret and covert. 
In the Covert Model, traditionalist military and defence preoccupations - in say defence academies - do not nowadays imply, nor perhaps did they ever, a disciplinary narrowness. The breadth of intelligence disciplines (Lowenthal \& Clark 2015) is testimony to this. And if the practical military/ defence applications of scientific knowledge and technology remain paramount (Singer \& Friedman 2014), the wider societal implications of such are part of long-established programmes of civil preparedness and public education in the wake of security threats posed by chemical, biological, nuclear and radiological weaponry threats pre-dating the Cold War (Preston 2015; Trenear-Harvey 2011).

\section{The overt model}

If the Covert Model makes plain the continuance of operational secrecy in higher education, training and research, the pressures of increased public accountability, to some degree forced by prominent leaks (particularly post-Snowden) reveal staggering scales of intelligence gathering, but has also as a result seen pressures for greater openness in terms of security and intelligence, and this includes relationships with universities. Thus, for example, the Intelligence Studies Section (ISS) at the International Studies Association (ISA) was created in the mid1980s as an academic focal point for the presentation of intelligence studies scholarship, and the ISS/ISA remains a primary focal point for intelligence studies scholars worldwide. This US academic initiative had transatlantic links to the United Kingdom and was part of a developing move to study the history of intelligence in Britain, the leading historian of MI5 (Andrew 2010).

Recent initiatives have shown, however, from recruitment to research, a marked multi-disciplinary engagement with universities and an attempt to cohere the objectives of higher education with the operational ends of the Intelligence Community (IC).

The United States has led the way here with its IC CAE programme (ODNI 2005). Ostensibly fulfilling an equal opportunities mandate - 'to create an increased pool of culturally and ethnically diverse, multi-disciplinary job applicants for the Intelligence Community' - its overt strategy has been to build 'long-term partnerships with selected universities across the nation to support the development of sustainable national security and intelligence education programmes which produce a cadre of qualified job applicants'. In other words, this initiative provides an opportunity for the IC to filter applicants as part of a recruitment process, which also serves both educational needs and security requirements, '... to design, develop and reshape Intelligence and National Security-Related Curricula in disciplines that align with IC mission-critical skills and competencies' and '... to conduct Intelligence \& National Security-Related Research in support of building intellectual capital within interdisciplinary fields of study ...' (DIA 2015).

This environment has enabled the flourishing of academicintelligence community networks such as the IAFIE.
IAFIE's 11th (2015) conference was on 'Standards for Intelligence Education'. IAFIE has also defined benchmark standards for undergraduate and postgraduate courses, including on themes of Intelligence History, Intelligence Organisations, Intelligence Planning, Intelligence Collection, Intelligence Analysis as well as Counterintelligence and Security. Just as '[a]t least half' of IAFIE graduates chose 'CIA careers' (IAFIE 2016), in the United Kingdom, recruitment to MI5, MI6 and the GCHQ manifests this new overt orientation, specifically targeting graduates across academic disciplines (MI5 2016; MI6 2016; GCHQ 2016). The IAFIE's 12th anniversary and 1st international conference, at Breda in the Netherlands in June 2016 has formally expanded the international remit of the association, as its conference title indicates: 'Connecting Intelligence Education Communities: Europe, North America and Beyond' (IAFIE 2016).

An increased openness has been marked also in the United Kingdom, though less systematised, with the relationships between universities and the Intelligence Community; thus, the emergence of centres specifically for security and intelligence studies at Aberystwyth, Birmingham, Brunel, Buckingham, Nottingham, St Andrews, and Warwick, among others. In this context, the Oxford Intelligence Group, based at Nuffield College, University of Oxford, and the Cambridge Intelligence Seminar, at Cambridge University have a particularly close relationship between academic research and intelligence agencies, acting as conduits for the sharing of new knowledge in the field, in the disciplinary and operational sense. In broader security research terms, the UK Government through Research Councils United Kingdom have provided substantial - though compared to the United States, trifling - resources into 'New Security Challenges' (for a critical assessment of recent research on terrorism, radicalisation and violence, see Tilley, Bouhana \& Braithwaite 2014).

\section{The covert-overt model}

The idea that university academics might be covertly engaged in espionage while overtly engaged in perfectly open scholarly duties has long been the stuff of fiction. From the classic 1930s and 1940s spy-thrillers of Eric Ambler and Graham Greene to John le Carré, Len Deighton and Ian Fleming; and no little part of the fascination of these shadowy figures' covert passage through the world of international espionage has been in their educational formation, at school and university, which all the spy novelists listed use to varying degrees to fill in a backstory to their intrigues. Contemporary novels of the genre also have an uncanny tendency to have art (covertly of course) mirror life. Against the backdrop of international terrorism, war in Iraq and UKUS complicity in the extraordinary rendition and torture of terrorist suspects, the bestselling author Robert Harris's book The Ghost tells the story of an author ghost-writing the story of a former British Prime Minister, and that the PM's wife, unknown to the PM himself, had been secretly recruited as a student by a distinguished Harvard Professor into the CIA, part of an American plot to influence British foreign policy. 
And the number of spies who turn themselves to fiction is notable, including some from the highest ranks of intelligence such as Stella Rimington, former Head of MI5. Indeed, the spy novel itself has itself flourished; interestingly, perhaps in our era of ever greater openness, there is a seemingly insatiable appetite for the ultimate in privacy.

However, the undercover or covert operation of academics within universities is not simply a fictional construction. Indeed, because of the very secretive nature of intelligence operations, we are not likely to know the extent of such covert operations, except on occasions of scandalised exposure. In June 2006, for example, the Times Higher Education reported that 'CIA outrages UK academics by planting spies in classroom'. With overtures of Graham Greene's The Quiet American, it proclaimed that 'The revelation that the quiet American studying at a university near you might be a trainee spy brought cries of consternation from British anthropologists ...' In 2012, Bloomberg Technology (2012) reported on the claim that US universities were 'infected by foreign spies'.

Yet, there should be no surprise here. We are reminded again by Sinclair (1986) and Winks (1987) of the significant historical role higher education has had in and on the world of security and intelligence. If the Cold War was important for the realisation (notably with the Klaus Fuchs atomic spy scandal) that universities could be decisive centres for scientific and technological knowledge, it was (again Risso 2014) also a time when the arts, humanities and social sciences also came to be regarded as of security and intelligence use (Piette 2009; Saunders 2013).

As geopolitical threats alter, so do security and intelligence responses, and in an age of global terrorism, counterterrorism efforts have sought new relationships with universities, where multi-disciplinary solutions can be sought for new problems (Crosston 2013). However, suspicions remain that the apparent openness of academic endeavour activity is but a ruse for the covert securitisation of universities (Zwerling 2011). Such anxieties often have well-founded evidence to support their claims (see Price 2004). High-profile exposes of intelligence agents' undercover activity while ostensibly undertaking a university education was provided by the case of Valerie Plame and seemed to involve issues at a high level of State, the exact nature of which remain classified (NYT 2005).

\section{Conclusion}

Multiple levels of concern arise here, from integrity to intrusion, to academic freedom, freedom of speech, thought and expression, to anxieties over surveillance and professional trust between colleagues and between staff and students (UUK 2012; Russell Group 2015).

However, at the most foundational level, the most basic concerns from the academic community are, I sense, more visceral. They arise over the academic uses or application of knowledge, complicity of academics in security and especially direct military engagement. As suggested, more fundamental than any commonly and explicitly stated concerns expressed by universities and academics, it is likely not simply the specifics of challenge to academic integrity nor academic freedom or ethics or even intrusion that is resented and (within the legal limits of which this is possible) resisted but the very process of securitisation itself.

Yet, from a security and intelligence perspective, the very purposes of the university are increasingly seen as potentially serving the objectives of the security and intelligence agencies. Given the secretive nature of the latter, it can be assumed this relationship has not always, indeed we know it has not always, been open. It has become more contested today because of the greater openness and become intensified with current terrorist threats. This current terrorist threat is not likely in the near future to disappear. Nor are new forms of an old relationship between security/intelligence agencies and universities likely therefore to lessen.

An emergent securitised concept of university life is important because de facto it will potentially effect radical change upon the nature and purposes of the university itself.

It seems, then, that as in so much else Sherman Kent was prescient in his assessments. He had, as we have noted, long ago suggested the need for security and intelligence to have its own determinant literature. It now has this. Sherman Kent also provided literature with the aphorism that 'Intelligence is knowledge'. In this article, I have intimated in some brief, concisely elaborated ways, the manner in which the intelligence-gathering impulse of security agencies have gravitated to those types of institution we call universities, where knowledge provides their very raison d'etre. How far the foundational aims and purposes of the university itself as an institution will be (further) transformed is a matter of concern for those working in and across all academic disciplines. But we should not shield ourselves from selfevident Open-Source facts that the aims of terrorism as manifest today may well be altering the aims and purposes of the university in ways we as yet do not fully know or understand.

\section{Acknowledgements Competing interests}

The author declares that he has no financial or personal relationships which may have inappropriately influenced him in writing this article.

\section{References}

Agrell, W., 2012, 'The next 100 years? Reflections on the future of intelligence', Intelligence and National Security 27(1), 118-132. http://dx.doi.org/10.1080/026 84527.2012.621601

Aldrich, R.J., 2001, The hidden hand: Britain, America and Cold War Secret Intelligence, John Murray, London.

Aldrich, R.J., 2011, GCHQ, The uncensored story of Britain's most secret intelligence agency, Harper, London.

Aldrich, R.J., Andrew, C. \& Wark, W.K. (eds.), 2008, Secret intelligence: A reader, Routledge, London. 
Aldrich, R.J., Cormac, R. \& Goodman, M.S., 2014, Spying on the world: The declassified documents of the joint intelligence committee, 1936-2013, Edinburgh University Press, Edinburgh.
Proments of the

Allen, G.W., 1985, 'The professionalisation of intelligence', Studies in Intelligence 26(1), 23-31.

Anderson, D., 2015, The Terrorism Acts in 2014, Report of the independent reviewer of terrorism legislation, viewed 1 December 2016, from https:// Terrorism-Acts-Report-2015-Print-version.pdf

Andrew, C.M., 2010, The defence of the realm: The authorised history of MI5, London, Penguin.

Aradau, C., 2004, 'Security and the democratic scene, desecuritisation and emancipation', Journal of International Relations and Development 7(4), 388-413. http://dx.doi.org/10.1057/palgrave.jird.1800030

Argomanis, J., 2009, 'Post-9/11 institutionalisation of European Union Counterterrorism, emergence, acceleration and inertia', European Security 18(2), 151-172. http://dx.doi.org/10.1080/09662830903460103

Argomanis, J., Bures, O. \& Kaunert, C., 2014, 'A decade of EU counter-terrorism and intelligence: A critical assessment', Intelligence and National Security $30(2-3)$ 191-206.

Bakker, E., 2014, 'EU counter-radicalisation policies: A comprehensive and consistent approach?', Intelligence and National Security 30(2-3), 281-305.

Bellaby, R., 2012, 'EU counter-radicalisation policies: A comprehensive and consistent approach', Intelligence and National Security, 30(2-3), 93-117.

Breen-Smyth, M., Gunning, J., Jackson, R., Kassimeris, G. \& Robinson, P., 2008, 'Critical terrorism studies - An introduction', Critical Studies on Terrorism 1(1), 1-4. http:// dx.doi.org/10.1080/17539150701868538

Buzan, B. \& Hansen, L., 2009, The evolution of international security studies, Cambridge University Press, Cambridge.

Buzan, B., Waever, O. \& de Wilde, J., 1998, Security: A new framework for analysis, Lynne Rienner Publishers Inc., Boulder, CO.

Cavelty, M.D. \& Mauer, V., 2010, Routledge handbook of security studies, Routledge, London.

Chilcot, J., 2016, The Iraq inquiry, viewed 1 December 2016, from http://www. iraqinquiry.org.uk/the-report/

CIA, 2015, About CIA, viewed 1 December 2016, from https://www.cia.gov/about-cia/faqs

CIA, 2016, Central Intelligence Agency, viewed 1 December 2016, from https://www. cia.gov/index.html

Crosston, M., 2013, 'Occam's follies, real and imagined biases facing intelligence studies', Journal of Strategic Security 6(3), 40-53, viewed 1 December 2016, from http://scholarcommons.usf.edu/jss/vol6/iss $3 / 4$

Davies, P., 2002, 'Ideas of intelligence, divergent concepts and national institutions' Harvard International Review 24(3), 62-66.

Davis, J., 2002, 'Sherman Kent and the profession of intelligence analysis', The Sherman Kent Center for Intelligence Analysis, Occasional Papers, vol. 1, no. 5 , viewed 1 December 2016, from https://www.cia.gov/library/kent-centeroccasional-papers/vol1no5.htm

DHS, 2015, Department for Homeland Security, viewed 1 December 2016, from http://www.dhs.gov/

DIA, 2015, Intelligence Community Centers for Academic Excellence (IC CAE), viewed 1 December 2016, from http://www.dia.mil/Training/ICCentersforAcademicExcellence. Decem
aspx

DIA, 2016, Defence Intelligence Agency, viewed 1 December 2016, from http://www. dia.mil/

Dulles, A., 2006, The craft of intelligence, The Lyons Press, Guilford, CT.

Durodie, B., 2016, 'Securitising education to prevent terrorism or losing direction?', British Journal of Educational Studies 64(1), 21-35. http://dx.doi.org/10.1080/00 071005.2015.1107023

Dylan, H. \& Alexander, M.S. (eds.), 2012, 'A Century of British intelligence', Intelligence and National Security 27(1), 1-4.

$\mathrm{FBI}, 2016$, Intelligence branch, Federal Bureau of Intelligence, viewed 1 December 2016, from https://www.fbi.gov/about/leadership-and-structure/intelligencebranch

Felix, C., 1992, A short course in the secret war, Madison Books, Lanham, MD.

De Forest, J., 2004, 'Liam Gearon the human rights handbook: A global perspective for education, editor's review article', Harvard Educational Review, Fall, 340-345, viewed 1 December 2016, from http://www.hepg.org/her/abstract/47

Gearon, L., 2002a, Citizenship through religious education, Routledge, London.

Gearon, L., 2002b, Human rights and religion: A reader, Sussex Academic Press, Brighton.

Gearon, L., 2003, The human rights handbook: A global perspective for education, Trentham, Stoke-on-Trent and Sterling, VA.

Gearon, L., 2008, 'Religion, politics and pedagogy: Historical contexts', British Journal of Religious Education 30(2), 93-102. http://dx.doi.org/10.1080/01416200701843833

Gearon, L., 2012a, 'European religious education and European civil religion', British Journal of Educational Studies 60(2), 151-169. http://dx.doi.org/10.1080/000710 05.2012.671929

Gearon, L., 2012b, 'The securitization of religion in education', in T. van der Zee \& T. Lovat (eds.), New perspectives in religious and spiritual education, pp. 215-233, Waxmann, Münster.
Gearon, L., 2013a, Religious education MasterClass, Bloomsbury Academic, London.

Gearon, L., 2013b, 'The counter terrorist classroom: Religion, education, and security', Religious Education 108(2), 129-147. http://dx.doi.org/10.1080/00344087.2013. 767660

Gearon, L., 2015a, 'Education, security and intelligence studies', British Journal of Educational Studies 60(3), 263-279, viewed 1 December 2016, from http://www. tandfonline.com/toc/rbje20/63/3

Gearon, L., 2015b, On holy ground: The theory and practice of religious education, Routledge, London.

Gearon, L., 2016, 'The politicization and securitization of religion in education a response to a rejoinder', in 12th Triennial International Nuremberg Forum, viewed 1 December 2016, from http://www.nuernberger-forum.uni-erlangen.org/ Forum2016/Abstracts/abstract_gearon.pdf

Glees, A., 2015, 'Intelligence studies, universities and security', British Journal of Educational Studies 63(3), 281-310. http://dx.doi.org/10.1080/00071005.2015.1076567

Golden, D., 2012, American universities infected by foreign spies detected by FBI, Bloomberg Technology, viewed 1 December 2016, from http://www.bloomberg. com/news/articles/2012-04-08/american-universities-infected-by-foreign-spiesdetected-by-fbi

Greenwald, G., 2013, 'XKeyscore, NSA tool collects nearly everything a user does on the internet', The Guardian, viewed 1 December 2016, from http://www. theguardian.com/world/2013/jul/31/nsa-top-secret-program-online-data

Greenwald, G., 2015, No place to hide, Edward Snowden, the NSA and the surveillance state, Picador, London.

Gunning, J., 2007, 'Babies and bathwaters: Reflecting on the pitfalls of critical studies on terrorism', in ISA 2007 Annual Convention, Chicago, IL, February 28, 2007, viewed 1 December 2016, from https://www.aber.ac.uk/en/media/departmental/ interpol/csrv/babies-and-bathwaters---isa2007.pdf

Harding, L., 2014, The Snowden files: The inside story of the world's most wanted man, Guardian Faber Books, London.

Herman, M., 1996, Intelligence power in peace and war, Cambridge University Press, Cambridge.

Huysmans, J., 1995, 'Migrants as a security problem, dangers of "Securitising" societal issues', in R. Miles \& D. Thraenhart (eds.), Migration and European integration: The dynamics of inclusion and exclusion, pp. 53-72, Pinter, London.

IAFIE, 2016, International Association for Intelligence Education, viewed 1 December 2016, from http://www.iafie.org/

IRISS, 2015, Increasing Resilience in Surveillance Societies, viewed 1 December 2016, from http://irissproject.eu/

Jackson, R., 2015, 'The politicisation and securitisation of religious education: A rejoinder', British Journal of Educational Studies 63(3), 345-366. http://dx.doi.org/ 10.1080/00071005.2015.1069257

Jeffrey, K., 2011, The history of the secret intelligence service, Bloomsbury, London.

Johnson, L.K., 2012, The oxford handbook of national security intelligence, Oxford University Press, Oxford.

Kent, S., 1955, 'The need for an intelligence literature', Studies in Intelligence 1, 1-11.

Kent, S., 1966, Strategic intelligence for American World Policy, Princeton University Press, Princeton, NJ. (Originally published 1949)

Kent, S., 1968, 'Valediction', Studies in Intelligence 12(1), 1-11.

Lowenthal, M.M. \& Clark, R.M., 2015, The five disciplines of intelligence collection, CQ Press, Thousand Oaks, CA.

NYT, 2005, 'The Miller case: A notebook, a cause, a jail cell and a deal', viewed 1 December 2016, from http://www.nytimes.com/2005/10/16/us/the-miller-casea-notebook-a-cause-a-jail-cell-and-a-deal.html?_r=0

ODNI, 2005, Guidance and procedures of the intelligence community centers of academic excellence program, Office of the Director of National Intelligence, viewed 1 December 2016, from https://www.nsu.edu/Assets/websites/iccae/ pdf/Guidance-and-Procedures.pdf

OSCE, 2007, The Toledo guiding principles on teaching about religions and beliefs in public schools, Organisation for Security and Cooperation in Europe, Vienna, viewed 1 December 2016, from http://www.osce.org/odihr/29154?download=true

Pham, C., 2013, 'Effectiveness of metadata information and tools applied to national security', Library Philosophy and Practice, Paper 1077, viewed 1 December 2016, from $\mathrm{http} / / /$ digitalcommons.unl.edu/cgi/viewcontent.cgi?article=2608\&context=libphilprac

Piette, A., 2009, The Literary Cold War, 1945 to Vietnam, Edinburgh University Press, Edinburgh.

Preston, J., 2015, 'A golden age of security and education? Adult education for civil defence in the United States 1950-1970', British Journal of Educational Studies 63(3). http://dx.doi.org/10.1080/00071005.2015.1076565

Price, D.H., 2004, Threatening anthropology: McCarthyism and the F.B.I.'s surveillance of activist anthropologists, Duke University Press, Durham, NC.

Richardson, R., 2015, 'British values and British identity: Muddles, mixtures, and ways ahead', Review of Education 13(2), viewed 1 December 2016, from http://www. insted.co.uk/london-review-education.pdf

Risso, L., 2014, Propaganda and intelligence in the Cold War: The NATO Information Service, Routledge, London.

Russell Group, 2015, Russell Group response to the consultation on the counterterrorism bill draft statutory guidance, viewed 1 December 2016, from http:// www.russellgroup.ac.uk/uploads/57-Russell-Group-response-to-consultationon-the-Prevent-duty-guidance-as-described-by-the-Counter-Terrorism-andSecrurity-Bill-2015.pdf 
Saunders, F.S., 2013, The Cultural Cold War: The CIA and the world of arts and letters, New Press, New York

Schmid, A.P., (ed.), 2011, The Routledge handbook of terrorism research, Routledge, London.

Scott, L. \& Hughes, R.G., (eds.), 2008, Intelligence, crises and security, prospects and retrospects, Routledge, London.

Shulsky, A.N., 2001, Silent warfare, understanding the world of intelligence, 3rd edn., Brassey's, New York.

Sinclair, A., 1986, The red and the blue: Intelligence, treason and the universities, Widenfeld \& Nicolson, London.

Singer, P.W. \& Friedman, A., 2014, Cybersecurity and cyberwar, what everyone needs to know, Oxford University Press, Oxford.

Svendsen, A.D.M., 2013, Intelligence cooperation and the war on terror: AngloAmerican security relations after 9/11, Routledge, New York, NY.

Taureck, R., 2006, 'Securitisation theory and securitisation studies', Journal of International Relations and Development 9, 53-61, viewed 1 December 2016, from http://wrap.warwick.ac.uk/1082/1/WRAP_Floyd_Securitisation_theory_and securitisation_studies_WRAP.pdf

Tilley, N., Bouhana, N. \& Braithwaite, A., 2014, Evaluation of the ESRC/FCO/AHRC New Security Challenges: Radicalisation and violence - A critical assessment initiative ESRC, London, viewed 1 December 2016, from http://www.esrc.ac.uk/files/ research/evaluation-and-impact/new-security-challenges-radicalisation-andviolence-initiative/
Trenear-Harvey, G.S., 2011, Historical dictionary of atomic espionage, Scarecrow Press, Lanham, MD.

UK Gov, 2015, Counter terrorism and Security Act 2015, viewed 1 December 2016, from http://www.legislation.gov.uk/ukpga/2015/6/contents/enacted

UUK, 2012, Oversight of security-sensitive research material in UK universities, guidance, viewed 1 December 2016, from http://www.universitiesuk.ac.uk/ highereducation/Pages/OversightOfSecuritySensitiveResearchMaterial.aspx\#. VSSqEE3bLoY

Wæver, O., 1998, 'Security, insecurity and asecurity in the West-European Non-War Community', in E. Adler \& M. Barnett (eds.), Security communities, pp. 69-118, Cambridge University Press, Cambridge.

Wæver, O., 2004, 'Aberystwyth, Paris, Copenhagen: New schools in security theory and the origins between core and periphery', ISA Conference, Montreal, March 17-20, 2004.

Walton, T., 2010, Challenges in intelligence analysis, lessons from 1300 BCE to the present, Cambridge University Press, Cambridge.

Winks, R.W., 1987, Cloak \& gown, scholars in the secret war, 1939-1961, William Morrow and Company, Inc., New York.

Wright, D. \& Kreissl, R., 2013, European responses to the Snowden revelations, IRISS viewed from http://irissproject.eu/wp-content/uploads/2013/12/IRISS_Europeanresponses-to-the-Snowden-revelations_18-Dec-2013_Final.pdf

Zwerling, P., 2011, The CIA on campus: Essays on academic freedom and the nationa security state, McFarland \& Co Jefferson, NC. 